\title{
Evaluation of the reservoir architectural elements in deepwater turbidites of Niger Delta - a case study from the "AFUN" Field
}

\author{
Yemisi C. AJISAFE (1) \\ Department of Geology, Ekiti State University, Ado-Ekiti, Nigeria \\ e-mail: yemisi.ajisafe@eksu.edu.ng
}

\begin{abstract}
D post-stack time migrated seismic data and a suite of composite well log data from six wells drilled within the "AFUN" field Niger delta were used to effect a detailed interpretation of the field. This was with a view to delineating architectural elements that control reservoir quality of a deepwater turbidite reservoir. The data analyses were done using the Petrel software. LAS file of logs were imported into the Petrel software as well as SEG.Y. seismic data. Fault interpretation and horizon mapping were based on the well-seismic tie from the generated seismogram. Time and depth structure maps were created. Thirty faults which include growth faults, reverse faults, collapsed crest structure and as well as faults that are synthetic and antithetic to the growth faults were mapped. The growth faults are believed to act as pathways for the updip movement of hydrocarbon from the Akata Formation to Agbada Formation. The structural interpretation showed that the area has been subjected to compressional deformation which resulted in reverse faulting system in toe thrust zone influenced by shale diapirs. The maps revealed contour closures that belong to an anticlinal structure which is forming traps in the reservoirs. The structures are faulted North-South trending rollover anticlines. It has also been shown that the distribution and type of architectural elements i.e. fractures within the fan system have major impact upon the reservoir distribution, continuity and connectivity of sand/shale bodies. The study concluded that structural style and facies architecture are the two fundamental elements that defined the reservoir heterogeneity of the "AFUN" Field.
\end{abstract}

Key words: architectural elements, faulting system, reservoir, structural, compressional deformation

\section{Introduction}

Sedimentary structures affect initial reservoir quality by imparting a preferential flow pattern in the reservoir. Planar bedding, laminations or other stratification features can create stratified planar flow, especially if perme- 
ability barriers such as clay partings, fine-grained laminae, or graded beds are present. Slump structures may reduce permeability by creating a tortuous flow path, or may increase permeability (and porosity) by causing a looser grain packing and by producing small faults. Bioturbation typically decreases reservoir quality by mixing adjacent sands and clays, introducing the clay into the interstices among the sand grains (Marchand et al., 2002).

Fracturing and brecciation associated with folds, faults, and diapirs generally increase the reservoir quality of well-indurated rocks. Fracture porosity is typically low, usually providing only about $1 \%$ porosity. However, fractures in large reservoirs may hold considerable reserves. Fracture permeability may be as high as tens of darcies and directional in nature. Conversely, fractures filled by mineralization or with gouge may produce a permeability barrier in the direction perpendicular to the fracture. Brecciation along fracture or fault zones may occur due to shearing or dissolution and collapse. Except where mineralization has occurred in the breccia, brecciation can increase both porosity and permeability considerably. Closely spaced sealing faults can significantly compartmentalize a reservoir.

This study therefore intends to delineate the architectural elements that control the quality of deepwater turbidite reservoir of the "AFUN" field in the deep offshore of Niger Delta. The study area lies within water depth of about 990-1117 m (Fig. 1a). The study area is entrenched within the Gulf of Guinea at the Eastern Inner Fold Thrust Belt of the delta toe divided into lobes by the Charcot fracture zone. The lobes are characterised by numerous fracture zones (Corredor et al., 2005). "AFUN" Field (Fig. 1b) covers an area extent of approximately $812 \mathrm{~km}^{2}$ and has six oil wells drilled. The coordinates lie between $648000 \mathrm{~m}$ and $708000 \mathrm{~m}$ northing and $480000 \mathrm{~m}$ and $522000 \mathrm{~m}$ easting [conversion of latitude and longitude was done using geographic/UTM coordinate converter tool (https://www.hiwaay.net/)]. The seismic volume has inline range from 2300 to 4500, crossline range from 2067 to 4267 and time ranges from 0 to $6002 \mathrm{~ms}$. The sediments have been deposited during early to late Miocene (Reijers et al., 1997). The presence of multipore architecture within turbidite depositional environment makes their description from petrophysical point of view very complex. In order to understand the complex structure and stratigraphy of the field for prospect identification, a detailed structural framework of the study area was constructed. 


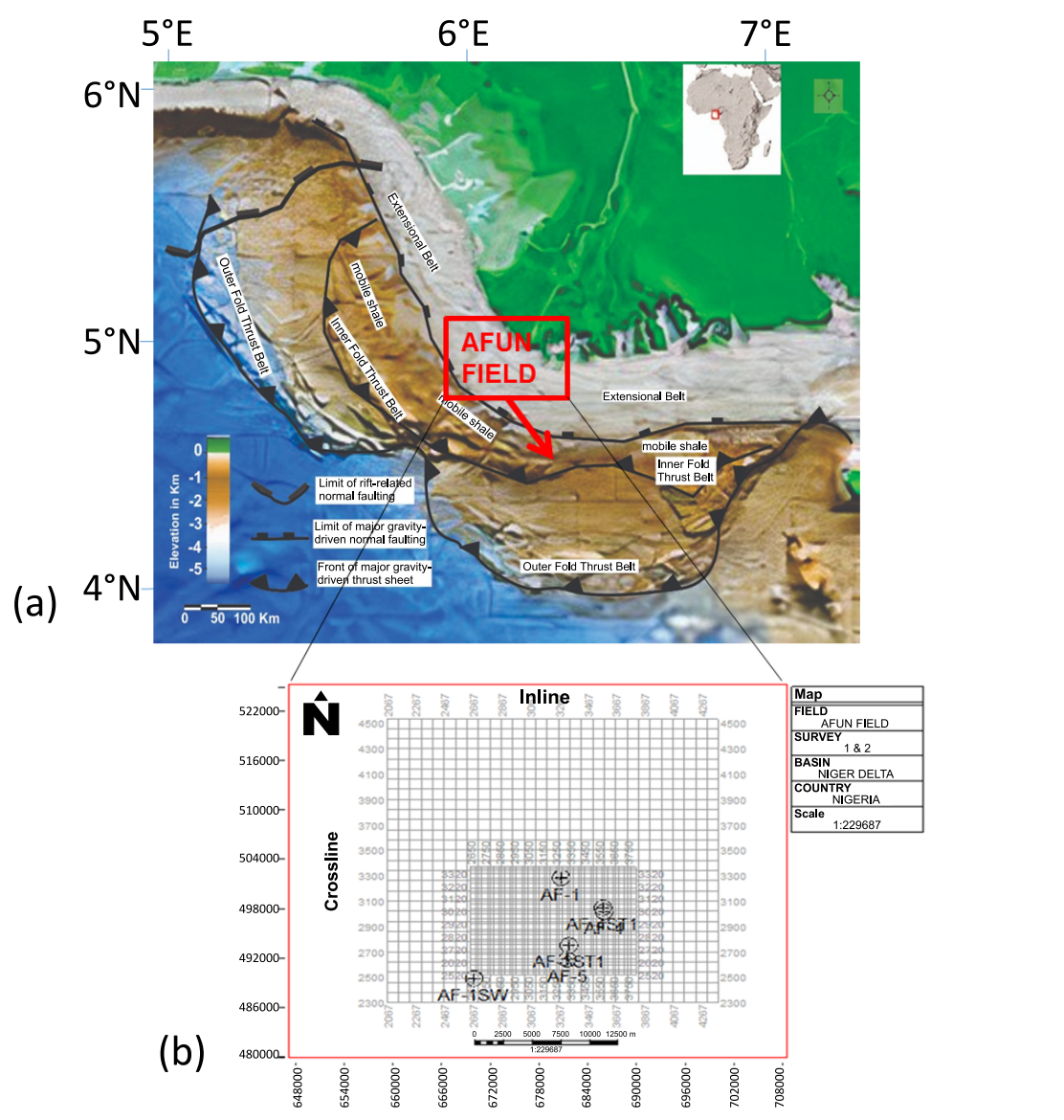

Fig. 1. (a) Map showing the location of the study area (Corredor et al., 2005), (b) Seismic survey area showing the spatial location of the wells.

\section{Geology of the study area}

The Cenozoic section of the Niger Delta is divided into three formations including Akata, Agbada and Benin Formation representing prograding depositional environments (Short and Stauble, 1967). The delta is $75000 \mathrm{~km}^{2}$ in size and reaches a maximum of $12 \mathrm{~km}$ in the centre of the basin (Whiteman, 1982). The Akata Formation at the base of the delta is of marine origin, and its thickness ranges from $2000 \mathrm{~m}(6600 \mathrm{ft})$ at the most distal part of the delta to $7000 \mathrm{~m}(23000 \mathrm{ft})$ beneath the continental shelf (Doust and Omat- 
sola, 1990). In the deepwater fold and thrust belts, the Akata Formation is up to $5000 \mathrm{~m}$ (16400 ft) thick because of structural repetitions by thrust ramps and the core of large detachment anticlines (Bilotti et al., 2005). The Akata Formation is composed of thick shale sequences that are interpreted to contain source rocks and may contain some turbidite sands (potential reservoirs in deep-water environments). On seismic sections, the Akata Formation is generally devoid of internal reflections (Fig. 2), with the exception of a strong, high-amplitude reflection that is locally present in the middle of the formation. This mid-Akata reflection serves as an important structural marker for defining detachment levels.
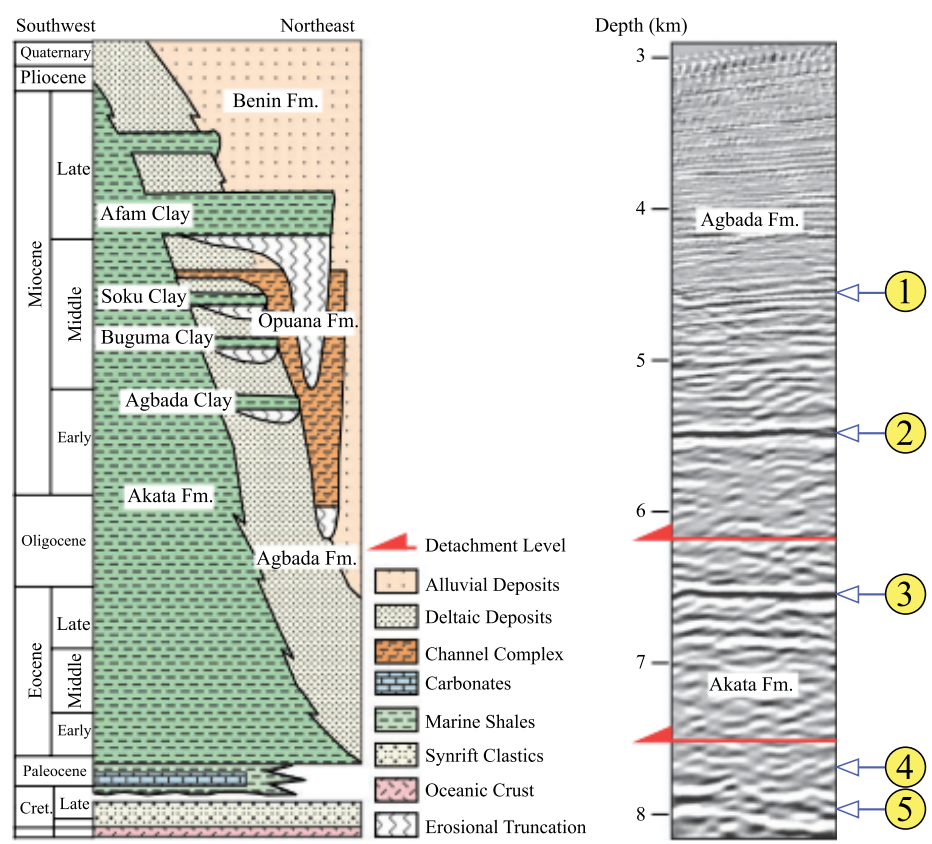

Fig. 2. Schematic diagram of the regional stratigraphy of the Niger Delta and variable density seismic display of the main stratigraphic units in the Outer Fold and Thrust Belt and main reflectors, including (1) Top of the Agbada Formation, (2) Top of the Akata Formation, (3) Mid-Akata reflection, (4) Speculated top of the Synrift Clastic Deposits, And (5) Top of the Oceanic Crust. Main detachment levels are highlighted with red arrows (stratigraphic section is modified from Lawrence et al., 2002).

The Offshore Niger Delta was originally divided into three structural zones (Damuth, 1994): an extensional zone I beneath the outer continental 
shelf and upper slope; an intermediate translational zone II beneath the continental slope; and a compressional zone III beneath the lower continental slope and uppermost rise. Connors et al. (1998) further subdivided the Niger Delta into five major structural provinces or zones based on structural styles imaged in seismic data and high-resolution bathymetry (Corredor et al., 2005). These structural zones (Fig. 3) include (1) an extensional province beneath the continental shelf that is characterised by both basinward-dipping (Roho-type) and counter-regional growth normal faults and associated rollovers and depocenters; (2) a mud diapir zone located beneath the upper continental slope, which is characterised by passive, active and reactive mud diapirs (Morley and Guerin, 1996), including shale ridges and massifs, shale overhangs, vertical mud diapirs that form mud volcanoes at the seafloor (Graue, 2000) and inter-diapir depocenters; (3) the inner fold and thrust belt, which is characterised by basinward verging thrust faults (typically imbricated) and associated folds, including some detachment folds; (4) a transitional detachment fold zone beneath the lower continental slope that is characterised by large areas of little or no deformation

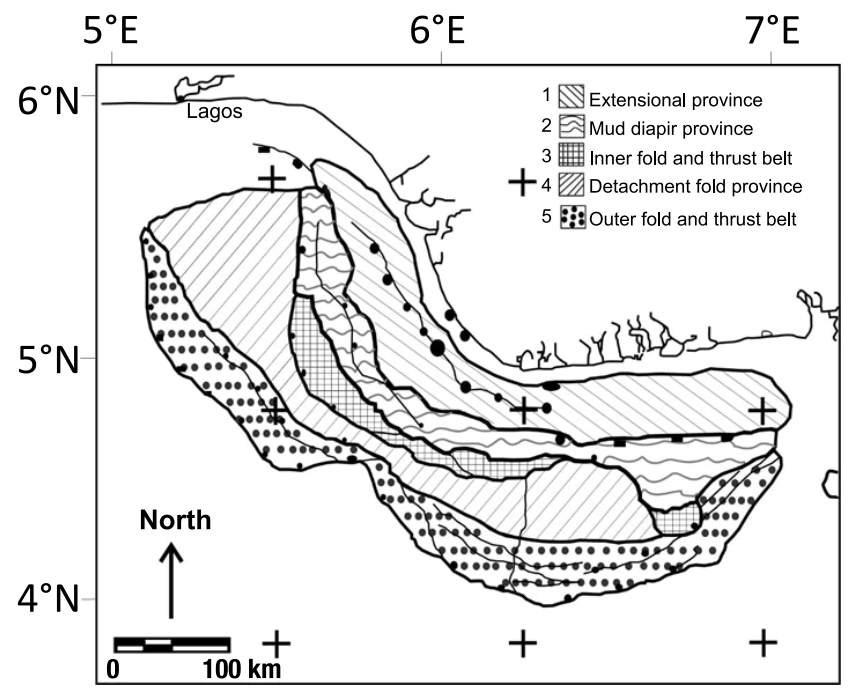

Fig. 3. Main structural domains of the Niger Delta showing (1) An Extensional Province beneath the Continental Shelf, (2) A Mud-Diapir Belt located beneath the Upper Continental Slope, (3) The Inner Fold and Thrust Belt, (4) A Transition Zone beneath the Lower Continental Slope, and (5) The Outer Fold and Thrust Belt (modified from Smith and Sandwell, 1997). 
interspersed with large, broad detachment folds above structurally thickened Akata Formation; and (5) the outer fold and thrust belt characterised by both basinward and hinterland verging thrust faults and associated folds.

Deformation across the structural provinces is active today, resulting in pronounced bathymetry expressions of structures that are not buried by recent sediments (Fig. 3). The inner and outer fold and thrust belts are mostly evident in the bathymetry, where ridges represent the crests of fault-related folds, and low regions correspond to piggyback basins formed above the back limbs of fault imbricates. The inner fold and thrust belt extend in an arcuate path across the centre of the offshore delta, whereas the outer fold and thrust belt consists of northern and southern sections that define two outboard lobes of the delta. These two lobes and their associated fold belts, are separated by a major rise in the basement topography that corresponds to the northern culmination of the Charcot fracture zone (Fig. 3). The break between the northern and southern sections of the outer fold and thrust belt results from thrust sheets being stacked in a narrow zone above and behind the major basement uplift (Connors et al., 1998; Wu and Bally, 2000).

A regional cross section (Fig. 4) that is based on a poststack-migrated and depth-converted seismic section across the southern delta was presented to illustrate the deformation styles of the different structural provinces in the Niger Delta. The position of the regional structural cross section is similar to the section presented by Hooper et al. (2002). On the north side of the section, both basinward-dipping and counter-regional growth normal faults are present in the extensional province beneath the continental shelf. Counter-regional normal fault systems consist of upper Miocene to lower Pliocene prograding sequences, whereas down-to-basin growth fault systems contain upper Pliocene and Pleistocene distal prograding units with shingled toe turbidites (Mitchum et al., 2000). A major detachment zone in the Akata Formation links the extensional province across the mud diapir zone to the contractional fold-thrust belts in the lower slope. Highly imbricated thrust sheets containing Cenozoic to Holocene delta-front to deep-marine sediments form the inner and outer fold and thrust belts. The two fold belts are clearly separated by a zone of little deformation (Ojo, 1996), which, along strike, is characterised by large detachment folds. Most thrust faults in these systems, with exceptions in the northern and central parts of the 
delta, verge toward the deep ocean and sole to detachment levels located inside the Akata Formation.

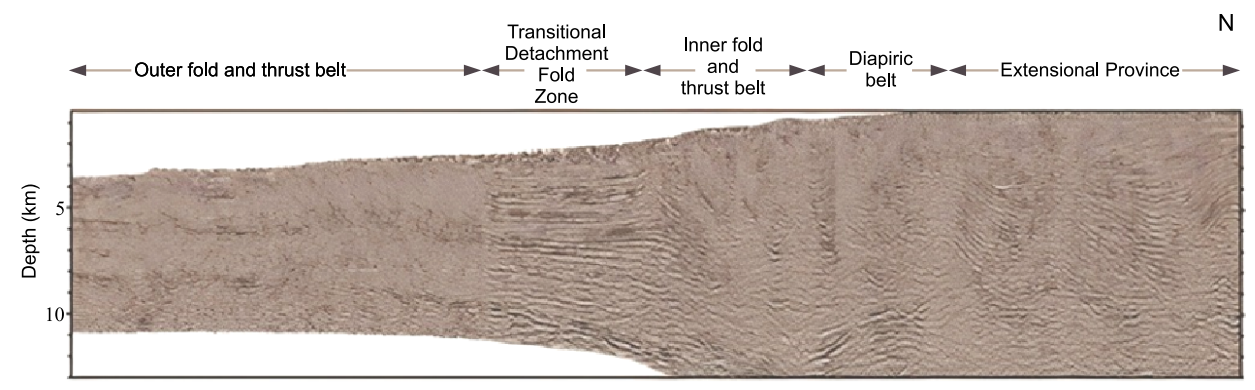

$0 \quad 10 \quad 20 \mathrm{~km}$

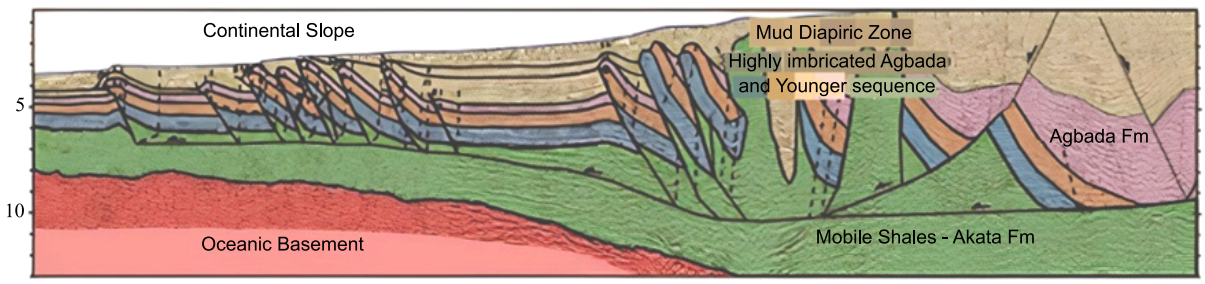

Fig. 4. Uninterpreted and interpreted regional seismic profile across the Niger Delta showing the link between the Extensional Province on the Shelf and the contraction in the Toe Thrust Systems in the Deepwater as well as the main structural domains (Corredor et al., 2005).

\section{Methods and data}

The datasets used for this study include post-stacked time migrated 3D seismic data comprises Vintage-1 and Vintage-2, six wells drilled (namely AF-1, AF-SW1, AF-3ST1, AF-4, AF- 4ST1 and AF-5, for proprietary reasons); five wireline logs (gamma ray, resistivity, neutron, density and sonic logs); checkshot (for all the six wells) and deviation data (indicate 3 deviated and 3 vertical wells). The data analyses were done using the Petrel software. Lithostratigraphic interpretation mainly focuses on the correlation of all hydrocarbon bearing sands within the field. This correlation was carried out using gamma ray and resistivity logs. Sand and shale bodies were delineated from the gamma ray log signatures. A combination of the gamma ray (GR) and resistivity logs (RES_D) were used to differentiate between the 
hydrocarbon and non-hydrocarbon bearing units. Well-log analysis was performed based on the study of Rider and Kennedy (2011). Sand units of interest were carefully picked and correlated across the wells to give an idea of the continuity of the reservoirs at different depths across the whole survey area. For the lithostratigraphic correlation, seventeen (17) reservoir sands namely B1, B2, C1, C2, C3, C4, C5, C6, D1, D2, E1, E2, F1, G1, G2, G3 and G4 were correlated for the study. The three horizons mapped, namely C4-sand, F1-sand and G1-sand were chosen based on the net pay of the hydrocarbon bearing sand and the sand quality. During the horizon mapping seismic facies analysis (Mitchum et al., 1977, 2000; Badley, 1985; Brown and Fisher, 1980) served as supporting tool. The terminology used in the subdivision of $3 \mathrm{rd}$ order sequences to system tracts follows Coe et al. (2003).

Stratigraphic study is always preceded by structural interpretation (Neal et al., 1993). Structural Smooth and Trace automatic gain control (AGC) volume attribute processes were applied on the $3 \mathrm{D}$ volume before being realised. These were done to increase the continuity of the seismic reflectors, boost weak events for improved interpretability and eliminate boosted noise. Structural analysis involved the application of seismic structural interpretation techniques, after tying the log markers (formation tops) to the seismic time section. This method involved the identification of prominent features such as major faults (i.e. fault interpretation), and the delineation/mapping of continuous seismic reflection events (i.e. horizon interpretation). This also entailed the integration of the two sets of the measurements, by building velocity model with a combination of check shots of the control well and stacking velocity of the area for the time-depth conversion. The model was used to generate the depth structure map of the interpreted horizons.

Fault mapping is an iterative process that utilised the three known orthogonal data slices of any 3D seismic data sets. The actual digitization of fault planes was done mainly on the dip oriented data slices (that is dip sections of the seismic data known as inlines), while the precision of picked fault planes were checked using the strike oriented data slides which is the strike sections of seismic data known as crosslines. The time slices are also used to tie interpretations made in both dip and strike sections at time interval of $20 \mathrm{~ms}$. Thereafter, additional sections were mapped between the interval inlines thereby bringing the interpreted seismic sections to alternate 
interval of 10 inline. Subsequently, fault mapping was occasionally refined to interval of every 5 inline along the defined traverse in order to facilitate adequate tracking of faults that were dying out or branching.

More also, imprints of the structure (faults and closures) which were observed from the time-slice, serves as a very good aid in guiding the structural interpretation. The consistency of the mapped fault planes was ensured by regular checks on the time slice, strike oriented seismic sections and on $3 \mathrm{D}$ visualization. Most of the faults seen on the seismic section were not continuous across the seismic volume, but major and minor faults that were continuous were mapped. These identified faults were assigned names, colour-coded and correlated. Thirty (30) faults including growth faults, reverse faults, collapsed crest structure and antithetic faults were mapped. The faults were then posted on the surfaces using the fault polygons.

A velocity function was generated using a third order polynomial as it is a better fit for the checkshot curve. Further adjustment to the velocity model was done using one of the available checkshots (i.e. AF-5). AF-5 well was used in generating the synthetic seismogram since it is the deepest well in the study area. The AF-5 checkshot (Fig. 5) was used to relate the

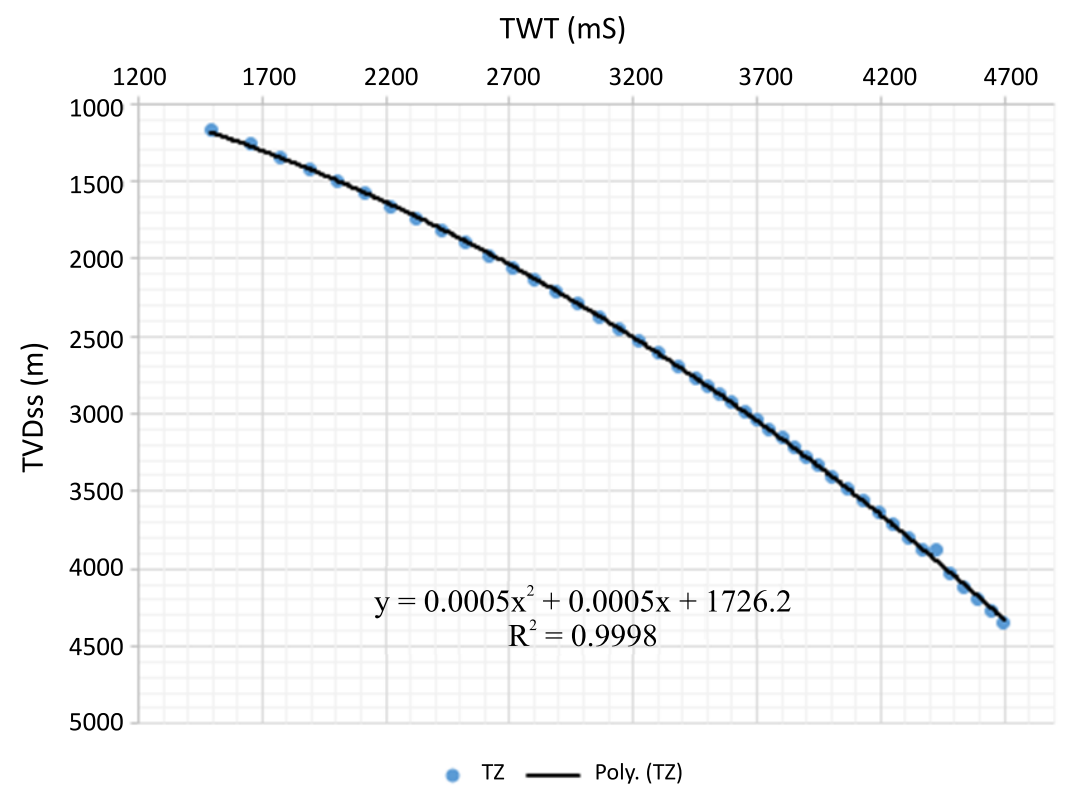

Fig. 5. Checkshot plot of the AF-5 well. 
seismic time to depth for all studied wells. Additional correction was made to the velocity model through the generation of a synthetic seismogram. A synthetic seismogram was generated in order to establish well-to-seismic tie. This was to enable correlation between well log information and seismic traces obtained within the vicinity of the well and then later propagate the match away from the well. Acoustic impedance property within well information was obtained using the combination of the product of sonic velocity and density log to match the seismic information. Sonic and density log were used for the seismic-to-well tie. This trace was compared with the composite seismic trace that was extracted in the volume along the deviated well path, on the nearest trace. Both synthetic and composite seismic traces were cross correlated. The alignment was carried out by shifting the synthetic trace up or down. The alignment was done by selecting several locations in both seismic traces, specifying and applying a shift function that varies with the travel time. The applied changes were validated before being converted into a new time-depth function that replaced the previous one. This was used to link the well data to the seismic data more reliably. The new AF-5 checkshot was shared for the other five (5) wells.

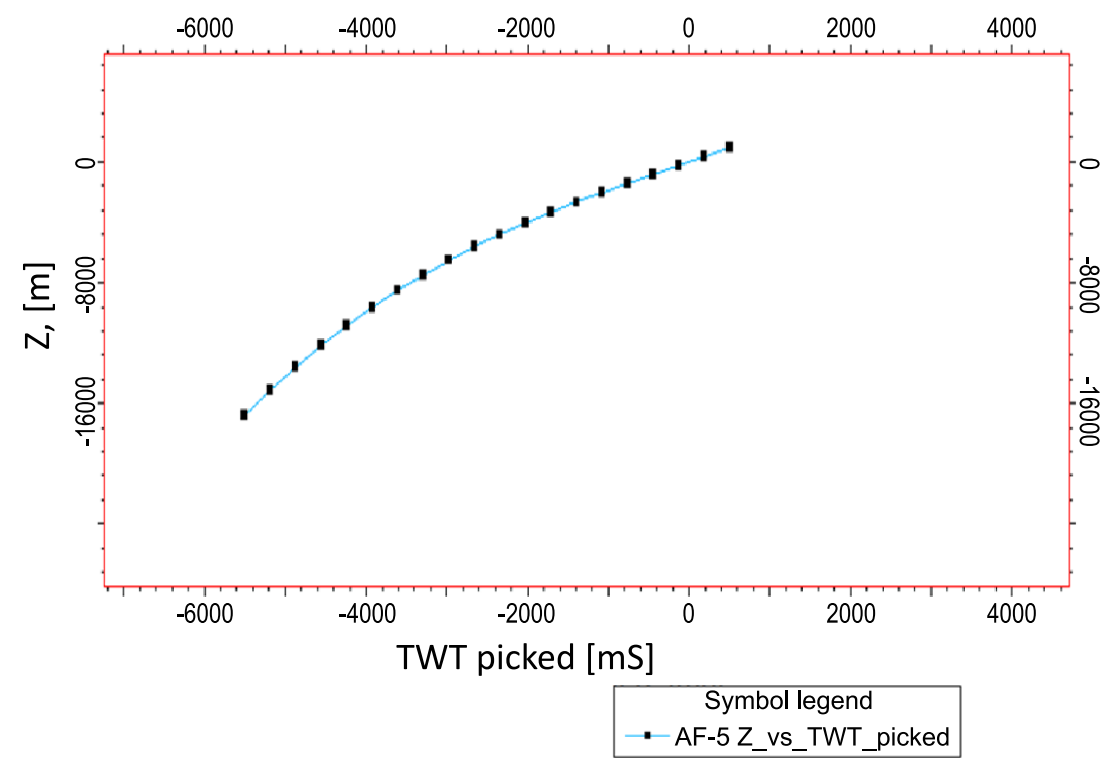

Fig. 6. Look-up function for time-depth conversion. 
A prelude to picking of seismic events is the identification of seismic events to be picked by tying the log markers (formation tops) to the seismic time section. The surface was identified by distinctive reflection pattern that can be observed over a layer with relatively large extent. Identification of prospective sand was available from the composite logs. With the well tied to seismic data, time horizons were identified, picked and interpreted. Horizon picking was manually carried out on every 10th inlines and crosslines. This mapping/digitization was done across the entire seismic volume.

Having finished with fault and horizon interpretation, fault polygons were generated from the interpreted faults. The polygons were renamed and converted from time to depth using the look- up function. Afterwards, time maps of the reservoirs were generated. The time maps were then converted to depth using look-up function (Fig. 6).

\section{Results}

\subsection{Well correlation}

From the lithostratigraphic panel, it can be deduced that there is reservoir discontinuity and lateral facies change, that is, thickening and thinning of reservoir (some reservoir pinch out from sand to shaly sand). It can also be deduced from the well correlation that the reservoir series are characterised by both lateral and vertical heterogeneities (Figs. 7 and 8). The reservoirs could be said to have been smeared by the continuous shale layers that occur between the sand bodies in the study area.

\subsection{Structural architecture}

The faults in the study area trend approximately E-W and dip significantly to the north and south directions (Fig. 9). The major (regional) growth fault F1 which is in blue colour is an elongate east-west trending fault that assisted the reservoir closure in trapping the reservoir oil. Other growth faults present in the study include F4 and F16. These faults are understood to act as pathways for the up dip movement of hydrocarbon from the Akata Formation to the Agbada Formation. It is revealed from the structural interpretation that the area has been subjected to compressional forces which resulted in reverse faulting system in toe thrust zone influenced by shale 


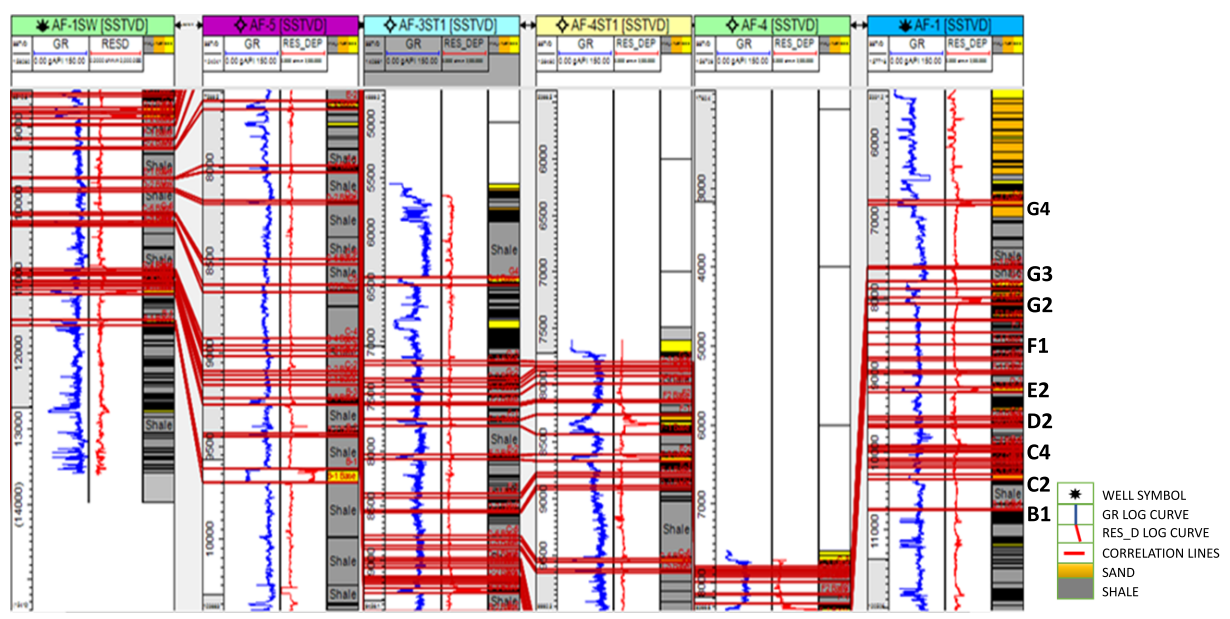

Fig. 7. Lithostratigraphic (Sand-to sand) correlation of AFUN Field's hydrocarbon bearing reservoirs.

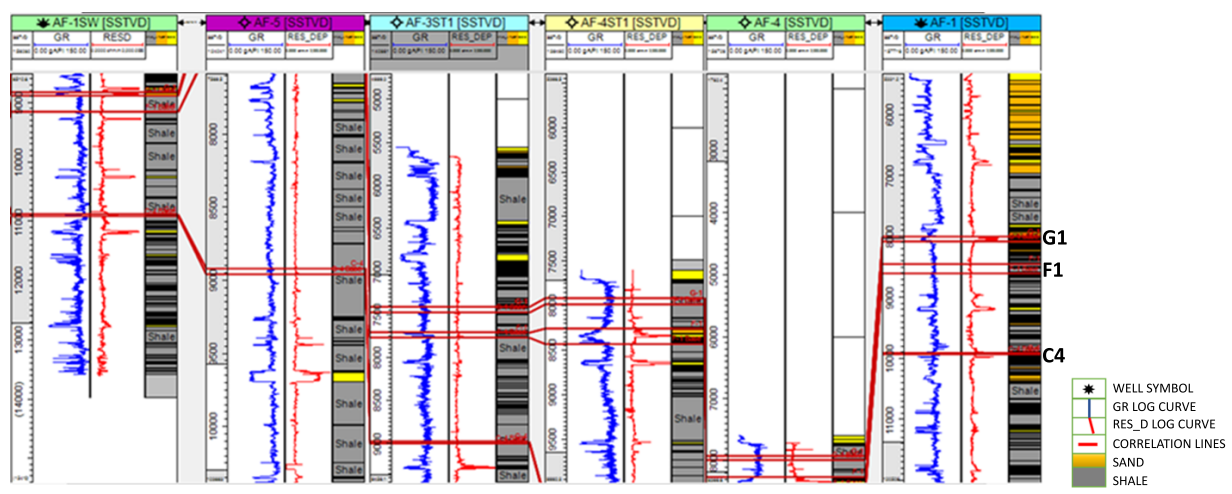

Fig. 8. Sand to sand correlation (G1, F1 \& C4).

diapirs (Fig. 10). The major reverse faults in the area include F23, F24 and F26. During a relative sea level fall, sediments were deposited as slope and basin fans following the structural trend imposed by the basin-bounding faults in the study area.

\subsection{Seismic-to-well tie}

Fairly good match was obtained in calibration of well to seismic trace. The uncertainties involved in this process were minimised by the understanding 

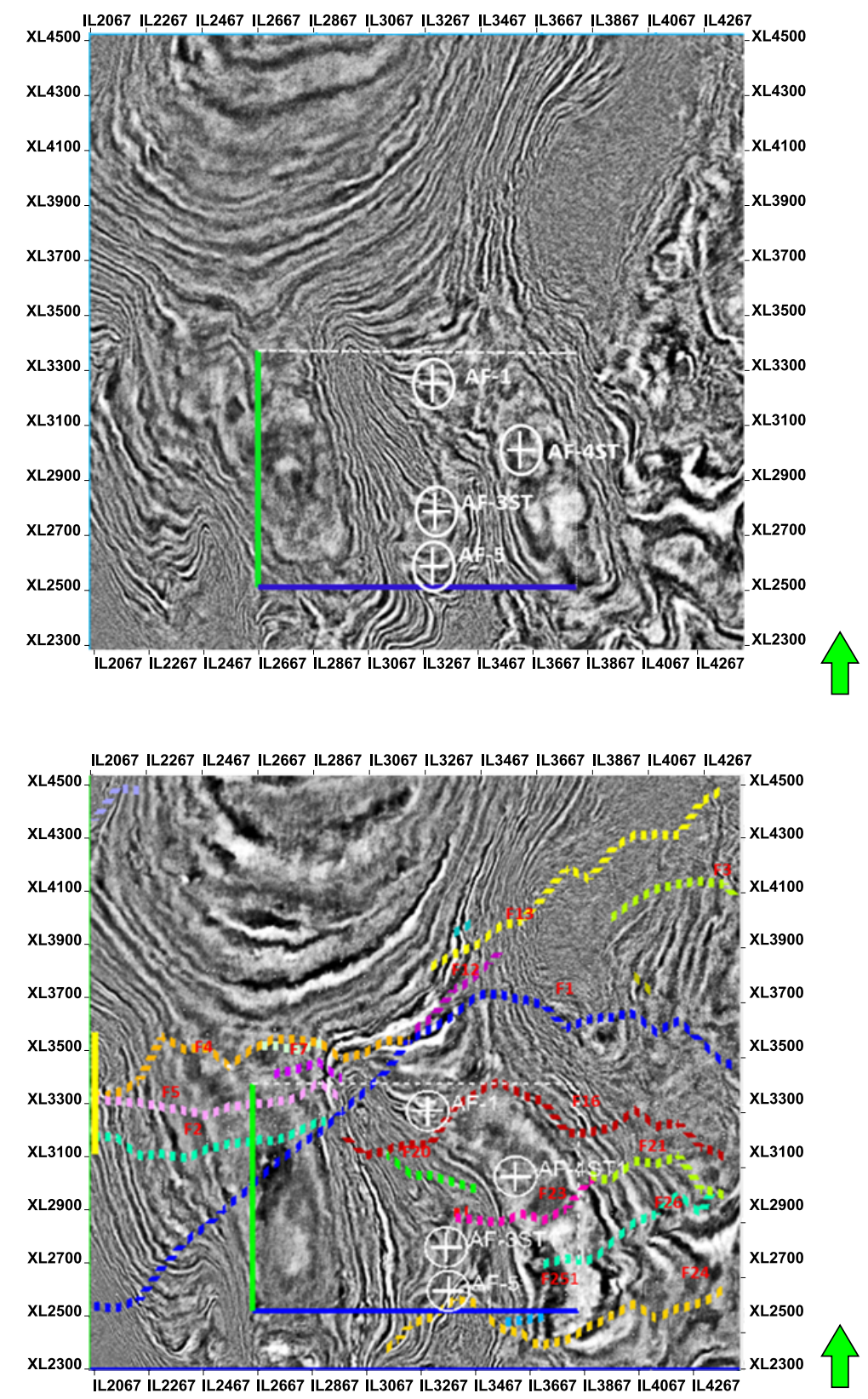

Fig. 9. Uninterpreted and interpreted Time Slice $4652 \mathrm{mS}$ showing mapped faults. 


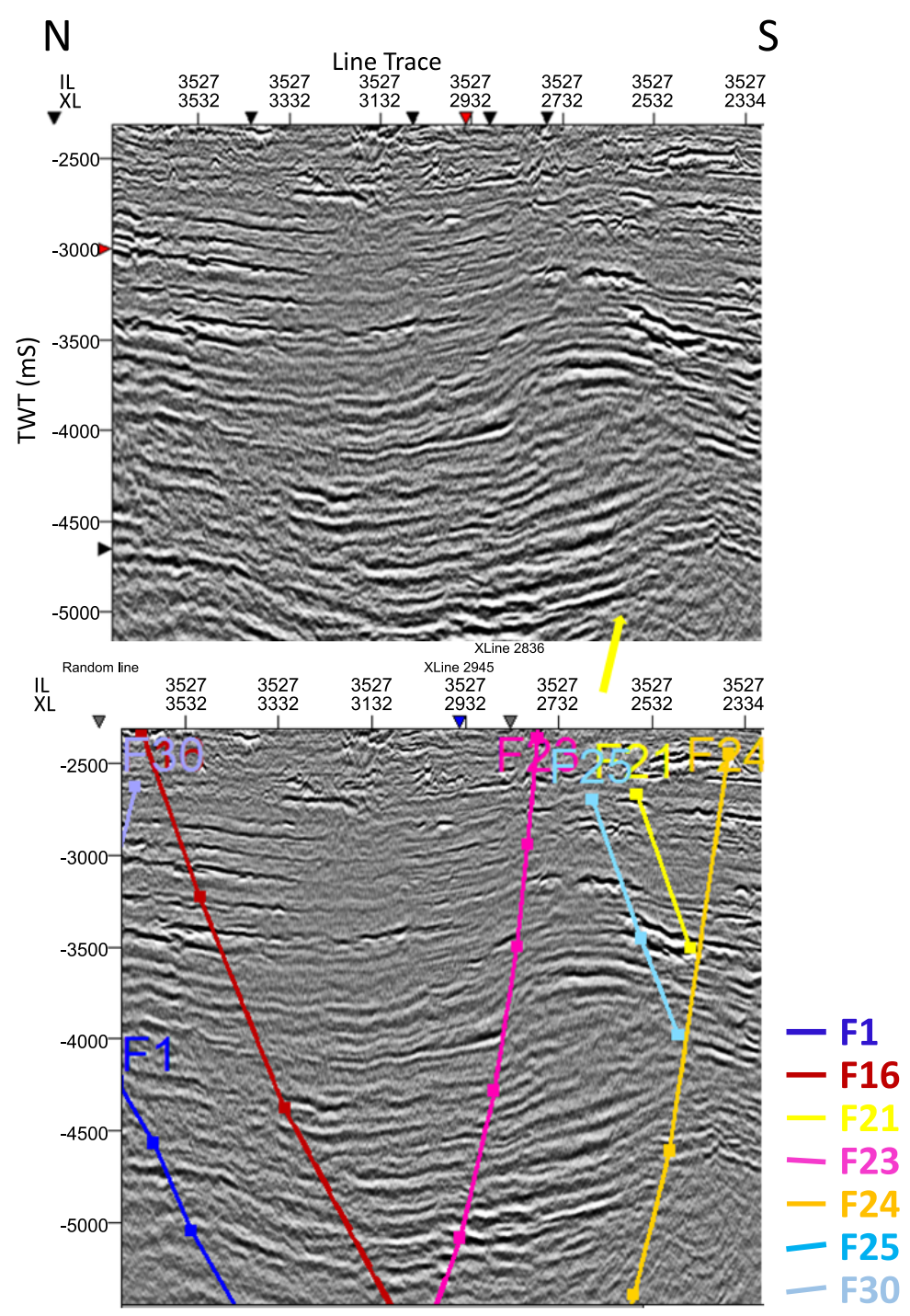

Fig. 10. Uninterpreted and interpreted reverse faulting system in toe thrust zone influenced by shale diapirs.

of the good reflectivity and continuity of the reflection pattern within the study area (Fig. 11). 
(a)
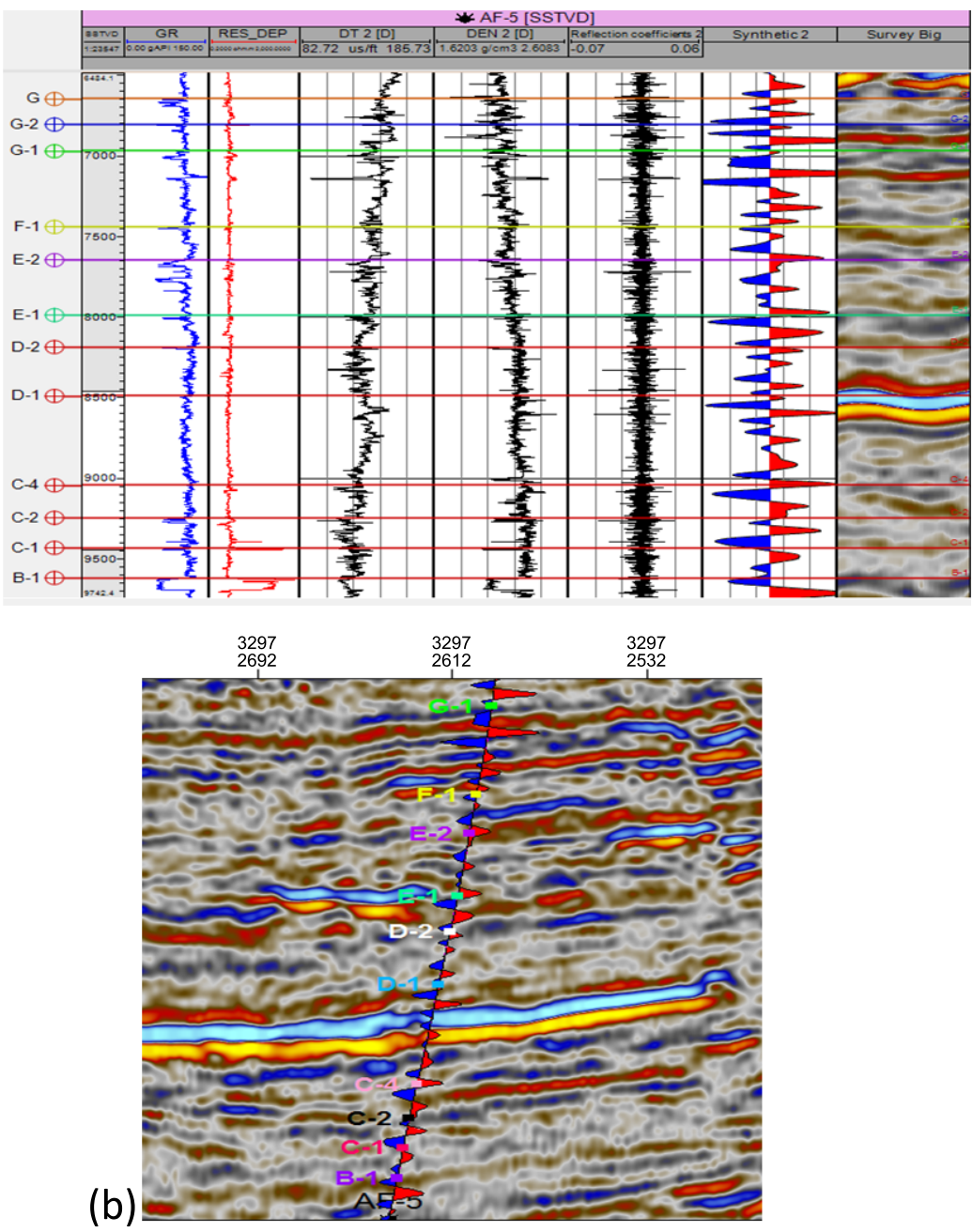

Fig. 11. (a) AF-5 generated synthetic seismogram display, (b) zoom synthetic seismogram imposed on the seismic display Inline 3297.

\subsection{Horizon mapping}

C4-Sand, F1-Sand and G1-Sand were mapped (Fig. 12) in order to delineate the discoveries and identify new drill potentials such as prospects and leads. These sands were mapped based on the well to seismic tie and strong 


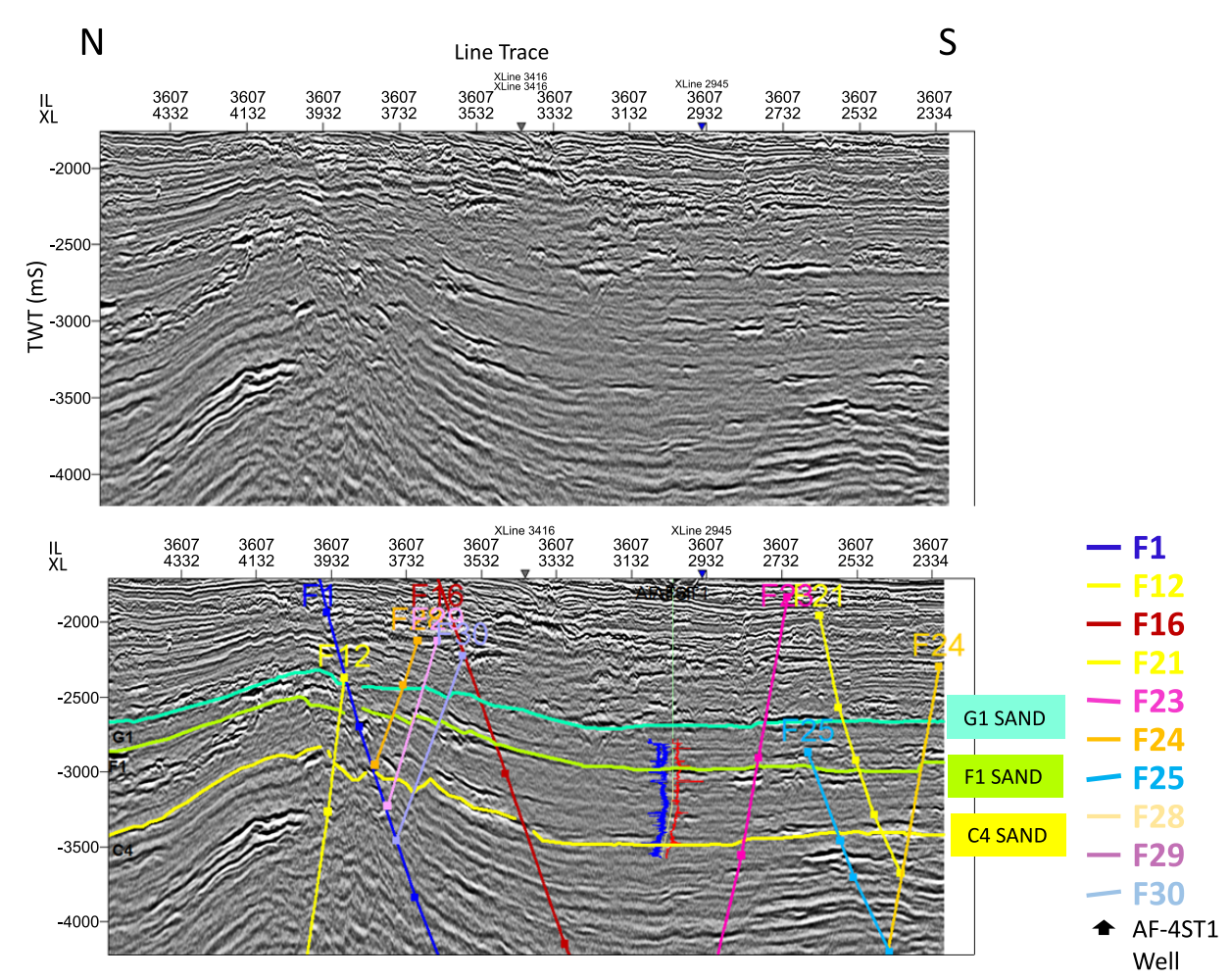

Fig. 12. Uninterpreted and interpreted seismic section Inline 3907 showing the fault framework and mapped horizons.

reflection of the seismic horizons. Two main types of seismic facies were identified namely: high amplitude, discontinuous and low amplitude, continuous reflection. The reflection pattern within the shallower level were characterised by alternating relatively high and low amplitude continuous events. Most of the seismic events within the deeper stratigraphic levels were essentially of high amplitude discontinuous reflection. Figs. 13 to 15 show the time structure maps for the sands. The red rectangular block denotes Vintage-1 explored area while the grey one indicates the diapiric zone. The map revealed some contour closures. The structure is a faulted northsouth trending rollover anticline. It can be deduced from the map also that the trapping mechanism in the study area is fault dependent. Generally, it was observed that the discoveries are within the seismic Vintage-1 at nearly the central part of the field. The southwestern part of the "AFUN" Field 


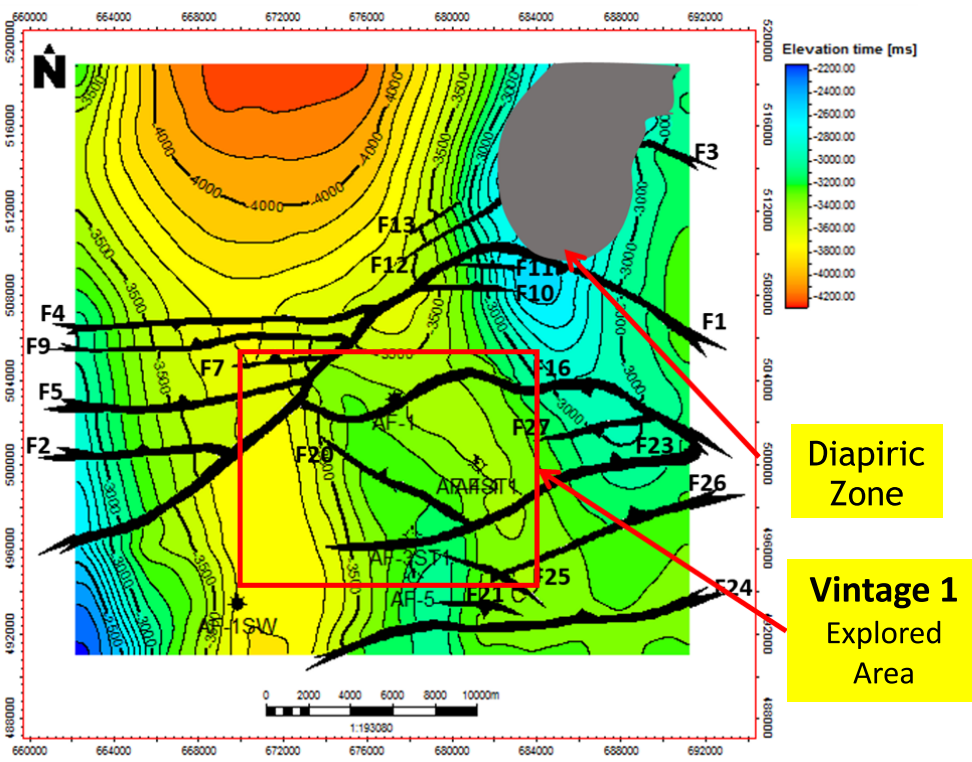

Fig. 13. Time structure map for C4-sand showing both diapiric zone and explored area.

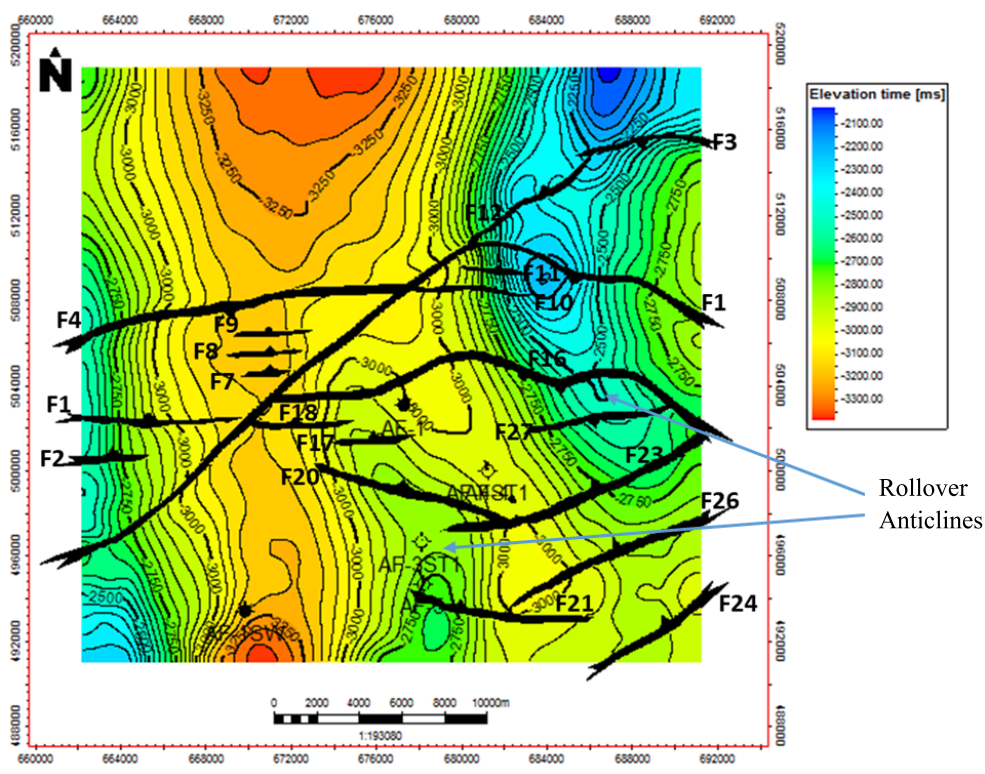

Fig. 14. Time structure map for F1-sand with fault assisted rollover anticlines. 


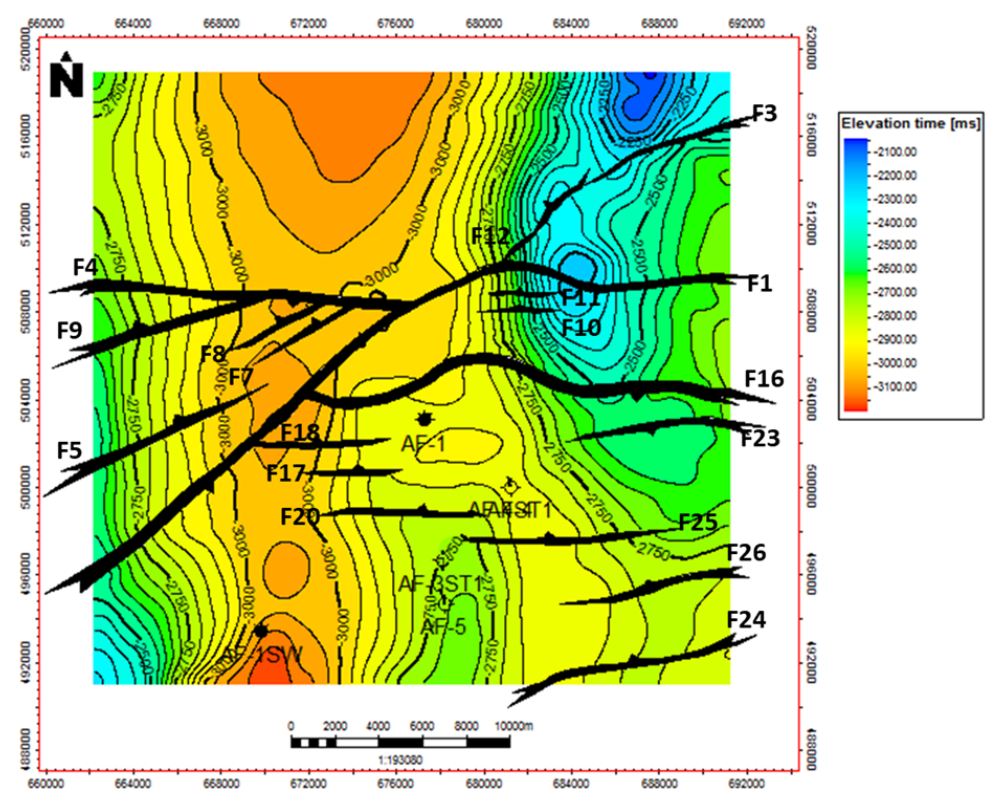

Fig. 15. Time structure map for G1-sand.

is bounded by viable prospects while the north eastern part of the field is bounded by diapiric zone. The time structure maps were converted to depth structure maps using checkshot data from AF-5 well. Figs. 16 to 18 show the depth structure maps of mapped sands within the area of interest. From these maps, the geological structure such as structural trap is visible, and it is easy to recognize that there are two main anticlinal structures forming trap for the reservoirs. The depth structure maps are similar to the time structure maps of the corresponding horizons as expected.

\section{C4 - Sand}

The C4-sand is one of $\mathrm{C}$ series of reservoir within the LST-3. The series are C1, C2, C3 and C4 in ascending order. The C4-sand is coarsening upward and has an average thickness of $30 \mathrm{ft}(9.14 \mathrm{~m})$. Four (4) wells penetrated the $\mathrm{C}$ series at interval. $\mathrm{C} 4$ was encountered in AF-1SW, AF-3ST1 and $\mathrm{AF}-1$.

The discovery at the $\mathrm{C}$ series is compartmentalised into both structural and stratigraphic compartments. For instance, C1-Sand was penetrated by 


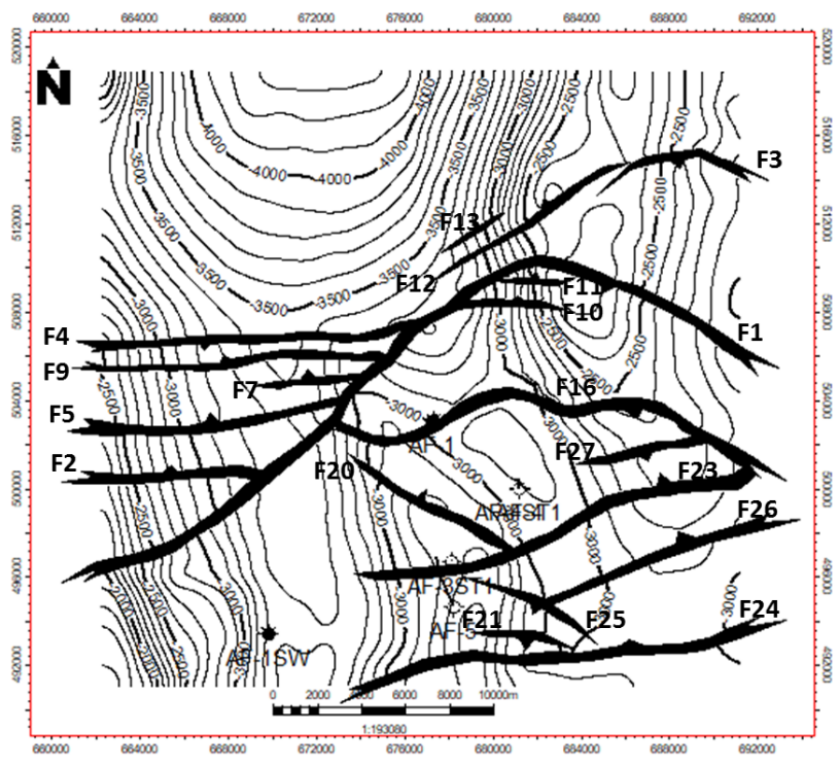

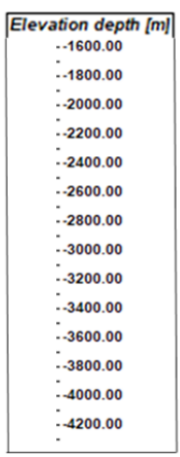

Fig. 16. Depth structure map for C4-sand.

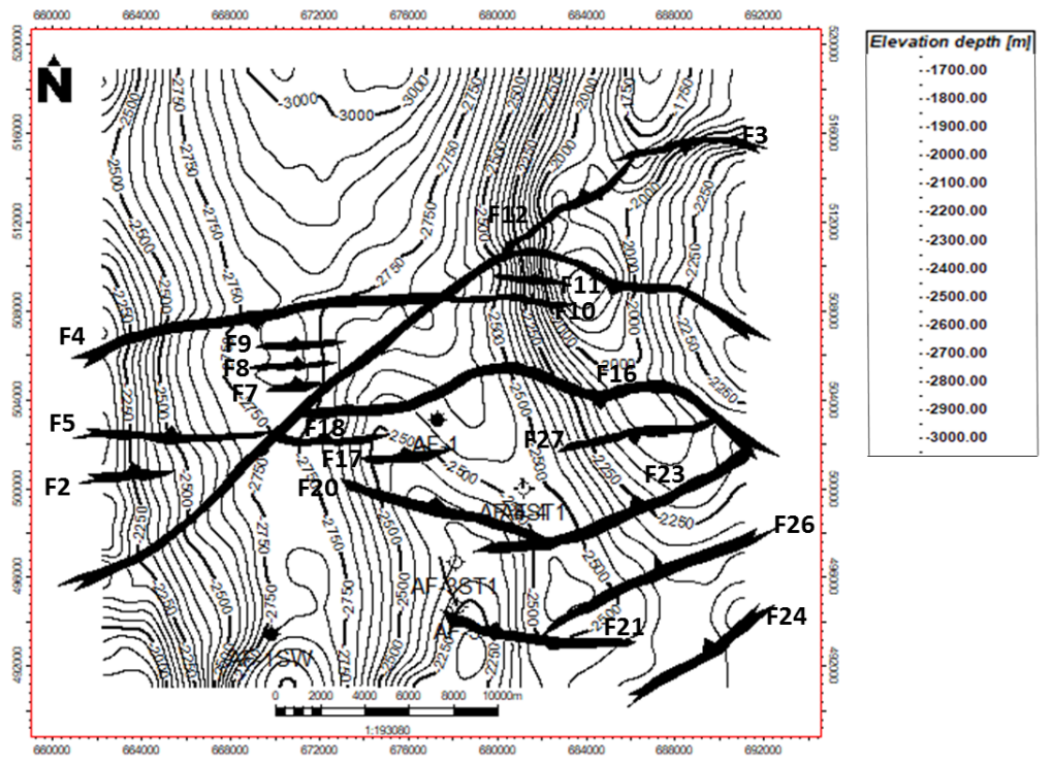

Fig. 17. Depth structure map for F1-sand. 


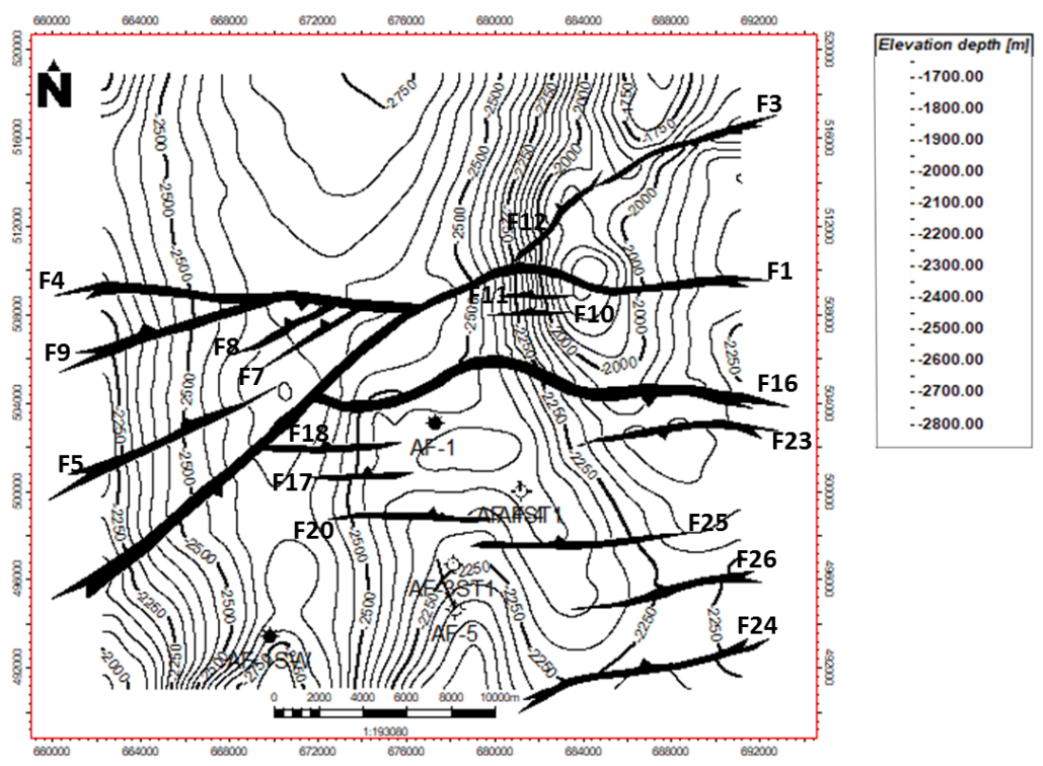

Fig. 18. Depth structure map for G1-sand.

wells AF-5 and AF-4ST1 but pinch out in AF-1 and not penetrated by AF3-ST1. C2 sand were encountered in well AF-5, AF-3ST1 and AF-4ST1, but shale out in well AF-1 while C3 was penetrated by AF-1 only. The structural compartment was due to the fact that the presence of F23 fault within the accumulation while the stratigraphic compartments were as a result of the lateral discontinuity of the reservoir sands. One prospect and one lead were identified and delineated (Fig. 19).

\section{$\underline{\text { F1 - Sand }}$}

F1-Sand is the shallowest reservoir within the LST-6. The series of F reservoir are overlain directly by the TST. F1-Sand is characterised by finning upward log motif from gamma ray log and has an average thickness of $170 \mathrm{ft}$ $(51.82 \mathrm{~m})$. Three discoveries exist within the reservoir. F1 reservoir at AF$3 \mathrm{ST} 1$ and AF-5 is wet at the crest of the structure but hydrocarbon bearing zone which is predicted to be possible reservoir at the syncline. The reservoirs are thickest at the syncline, thin at the crest of the structure and totally absent in AF-1. This is probably due to the tectonic movements 


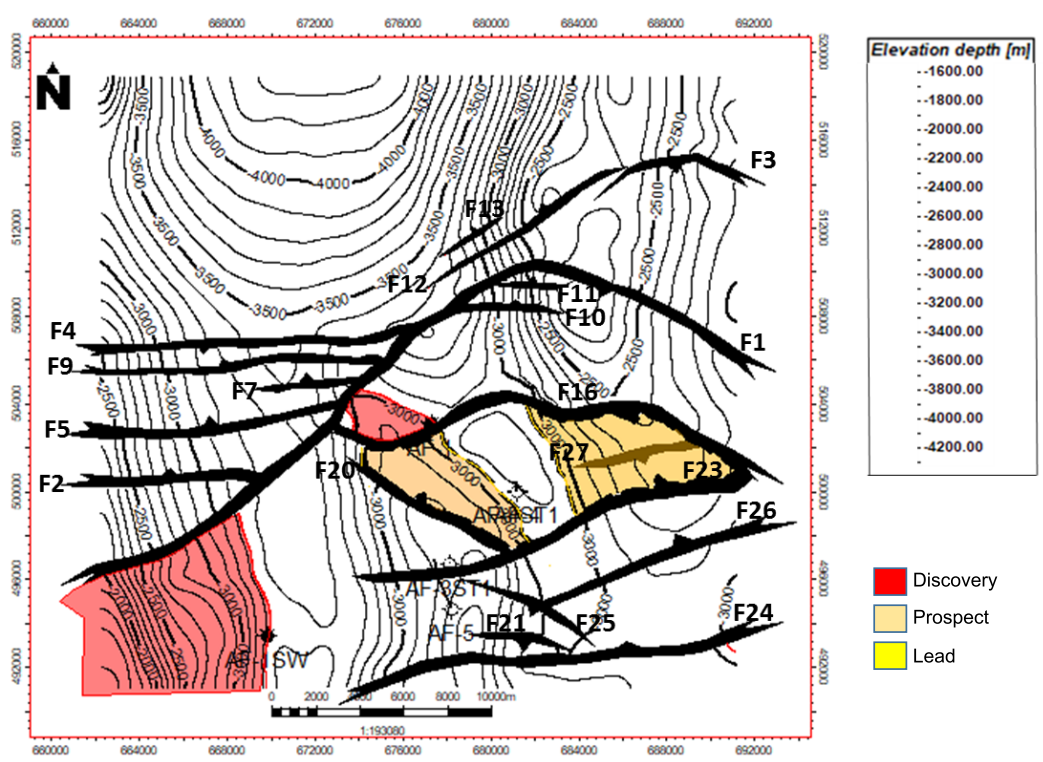

Fig. 19. Depth structure map for C4 showing the delineated prospect.

as result of mobile shale diapir and reoriented paleo-delta lobe deposited in the faulted syncline area. This modification of the delta lobe affected the distribution of favourable sandbodies and potential hydrocarbon traps. Two prospects were identified (Fig. 20).

\section{$\underline{\mathrm{G} 1-\text { Sand }}$}

G1-Sand is characterised by an almost even block trend with sharp top and base $\log$ motif at the well penetrated. Two discoveries exist within the reservoir and has an average thickness of $75 \mathrm{ft}(22.86 \mathrm{~m})$. AF-1 and AF-1SW wells penetrated the reservoir at possible oil interval while AF-3ST1 and AF-5 are dry. AF-4 and AF-4ST1 were not logged at this interval. Two prospects were delineated (Fig. 21).

\section{Discussion of results and implication of study}

The evaluation of the architectural elements usually influences the connectivity of reservoir units. More so, it is more important to understand the 


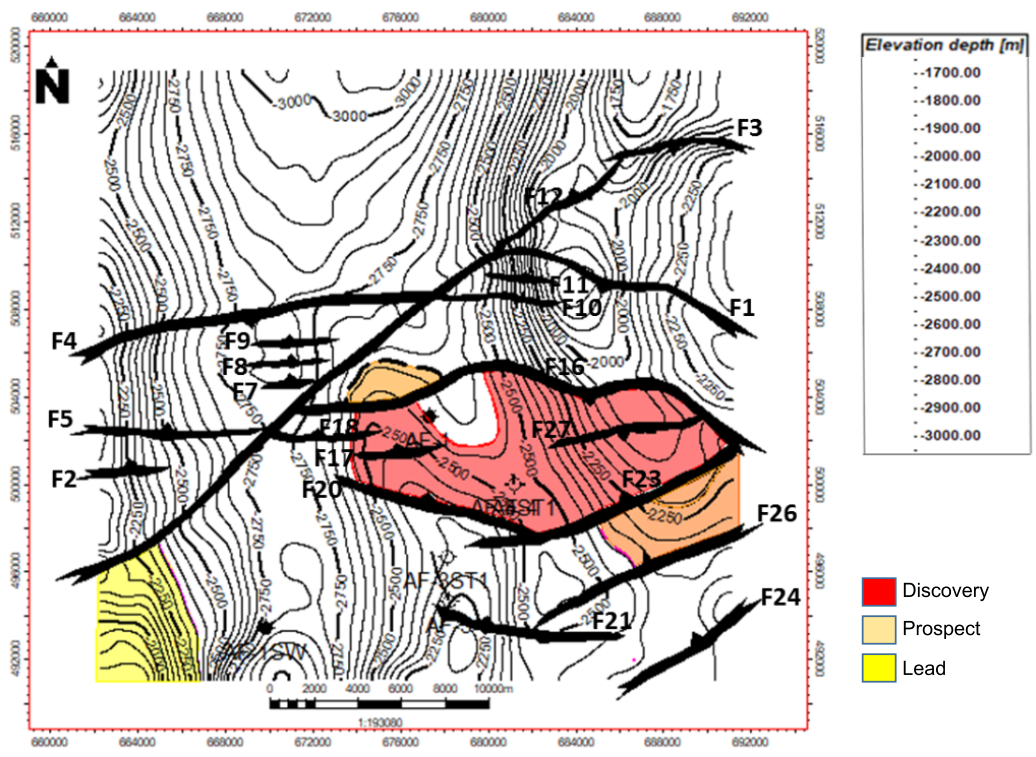

Fig. 20. Depth structure map for F1 showing the delineated prospect.

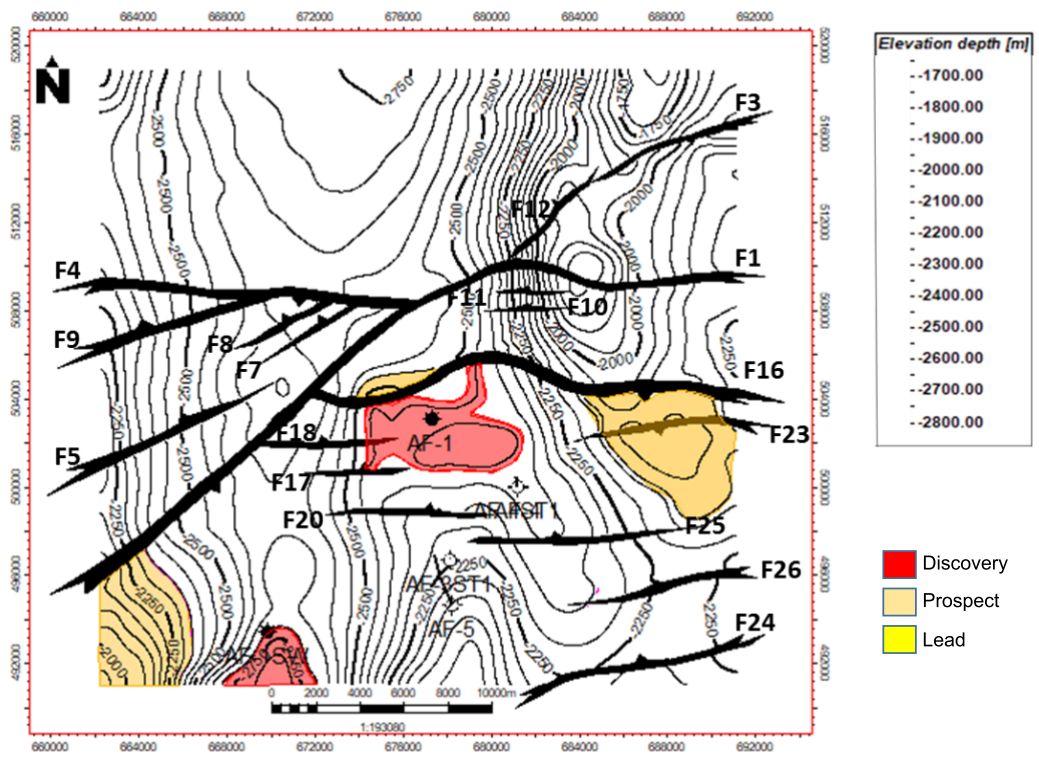

Fig. 21. Depth structure map for G1 showing the delineated prospect. 
structural framework of a deepwater turbidite because there is serious reservoir heterogeneity in the submarine fan, therefore it is very imperative to predict reservoir architecture in order to guide future exploration activity within the study area. This study has shown that, it is possible to delineate the reservoir architectural elements that control reservoir quality of deepwater turbidite of "AFUN" Field. In particular, all faults that exist within the study area were delineated, so as to establish the structural framework for each reservoir mapped. It was found (indicated in Fig. 9), that the distribution and type of architectural elements within the fan system have major impact upon reservoir compartmentalization and the distribution, continuity and connectivity of sand/shale bodies.

Traditionally, seismic data were interpreted based on structural interpretation to predict hydrocarbon reservoir among others. According to Haack et al. (2000), trap arrangement in the deepwater Nigeria is controlled by gravity driven system of linked extensional growth faults and compressional toe thrusts initiated during the Paleogene, when the modern Niger Delta was formed. This led to use of seismic structural interpretation techniques in this study. This technique involves the fault and horizon interpretation. The trapping mechanism of the study area is a combination of structural and stratigraphic elements which contributed to the varying degree of connectivity of the field. The field shows an extremely complex fault network. Most of the reservoir facies in the offshore Niger Delta are related to an aggrading lowstand complex where a slow relative rise in the sea levels allows sediment input to keep pace with the creation of accommodation space over a long period of time. A thick expanding edge of coarse clastics is trapped on the shelf behind the counter regional faults and most of the sediments are therefore, deposited on the shelf, indicating that the sand content and gross sediment input reduces dramatically with increasing distance from provenance. Normal faults triggered by the movement of deep-seated, overpressured, ductile, marine shale have deformed much of the Niger Delta clastic wedge (Knox and Omatsola, 1989; Obi et al., 2018). Many of these faults formed during delta progradation and were syndepositional, affecting sediment dispersal. Fault growth was also accompanied by slope instability along the continental margin. Faults flatten with depth onto a master detachment plane near the top of the overpressured marine shales at the base of the Niger Delta succession $(O j o, 1996)$. Subsequent or contemporaneous 
movement of ductile shale and growth faults have produced large structural closures resulting from simple and complex rollover structures that are domal in geometry but marked anticlinal with depth. These structures are common onshore and near offshore Niger Delta region (Thomas, 1995). It can be seen that better understanding of the structural configuration of the reservoir particularly at deepwater setting aids in developmental evaluation of geological complexity of the reservoirs.

\section{Conclusions}

The analyses of structural interpretation provided information on the subsurface structures and stratigraphy that enhanced the understanding of reservoir heterogeneities and prediction of sand availability in the study area. Thirty faults were mapped which include growth faults, reverse faults, collapsed crest structure and faults that are synthetic and antithetic to the growth faults. The growth faults are believed to act as pathways for the updip movement of hydrocarbon from the Akata Formation to the Agbada Formation. It was revealed from the structural interpretation that the area has been subjected to compressional deformation which resulted in reverse faulting system in the toe thrust zone influenced by shale diapirs. The synthetic seismogram generated was used to establish well to seismic tie. The tie was used to pick horizons to produce structure maps. The maps revealed contour closures that are anticlinal structure and form traps for the reservoirs. The structures are faulted North-South trending rollover anticlines. It has also been shown that the distribution and type of architectural elements i.e. fractures within the fan system have major impact upon the reservoir distribution, continuity and connectivity of sand/shale bodies.

Acknowledgements. The author wishes to express her sincere appreciation to Shell Nigeria Exploration and Production Company (SNEPCO) Port Harcourt, Nigeria for the provision of research data sets used in this research work. I must equally commend the efforts of Schlumberger for providing the software used for interpreting the data. I acknowledge the various authors whose works I have used extensively in this research work. Many thanks to the editor and anonymous reviewers for technical reviews and suggestions. 


\section{References}

Badley M. E., 1985: Practical seismic interpretation. International Human Resources Development Corporation, Boston, 266 p.

Bilotti F. D., Shaw J. H., Cupich R. M., Lakings R. M., 2005: Detachment fold, Niger Delta. In: Shaw J. H., Connors C., Suppe J. (Eds.): Seismic interpretation of contractional fault-related folds. AAPG Studies in Geology, 53, 103-104, doi: 10.1306 /St531003C13.

Brown L. F., Fisher W. L., 1980: Seismic stratigraphic interpretation and petroleum exploration. Continuing education course note series 16, AAPG, Tulsa, 56 p., doi: 10.1306/CE16409.

Coe A. L. (Ed.), Bosence D. W. J., Church K. D., Flint S. S., Howell J. A., Wilson R. C. L., 2003: The sedimentary record of sea-level change. Cambridge University Press, Cambridge, $287 \mathrm{p}$.

Connors C. D., Denson D. B., Kristiansen G., Angstadt D. M., 1998: Compressive anticlines of the mid-outer slope, central Niger Delta (abstract): AAPG Bulletin, 82, p. 1903.

Corredor F., Shaw J., Suppe J., 2005: Shear fault-bend fold, deep-water Niger Delta. In: Shaw J. H., Connors C., Suppe J. (Eds.): Seismic interpretation of contractional fault-related folds. AAPG Studies in Geology, 53, 87-92, doi : 10.1306/St531003C9.

Damuth J. E., 1994: Neogene gravity tectonics and depositional processes on the deep Niger Delta continental margin. Mar. Pet. Geol., 11, 3, 320-346, doi : 10.1016/0264 -8172 (94) 90053-1.

Doust H., Omatsola O., 1990: Niger Delta. In: Edwards J. D., Santoyiossi P. A. (Eds.): Divergent/Passive margin basin. AAPG Mem., 48, 239-248.

Graue K., 2000: Mud volcanoes in deepwater Nigeria. Mar. Pet. Geol., 17, 8, 959-974, doi: 10.1016/S0264-8172(00)00016-7.

Haack R. C, Sundararaman P., Diedjomahor J. O., Xiao H., Gant N. J., May E. D., Kelsch K., 2000: Niger Delta petroleum systems, Nigeria. In: Mello M. R., Katz B. J. (Eds.): Petroleum systems of South Atlantic margins. AAPG Mem., 73, 213-231.

Hooper R. J., Fitzsimmons R. J., Neil G., Vendeville B. C., 2002: The role of deformation in controlling depositional patterns in the south-central Niger Delta, West Africa. J. Struct. Geol., 24, 4, 847-859, doi: 10.1016/S0191-8141(01)00122-5.

Knox G. J., Omatsola E. M., 1989: Development of the Cenozoic Niger Delta in terms of the 'Escalator Regression' model and impact on hydrocarbon distribution. In: van der Linden W. J. M., Cloetingh S. A. P. L., Kaasschieter J. P. K., van de Graaff W. J. E., Vandenberghe J., van der Gun J. A. M. (Eds.): Coastal Lowlands: Geology and Geotechnology. Springer, Dordrecht., 181-202, doi: 10.1007/978-94-017-10 64-0_12.

Lawrence S. R., Munday S., Bray R., 2002: Regional geology and geophysics of the eastern Gulf of Guinea (Niger Delta to Rio Muni). Lead. Edge, 21, 11, 1112-1117, doi: $10.1190 / 1.1523752$. 
Marchand A. M. E., Smalley P. C., Hagzeldine R. S., Fallick A. E., 2002: Note on importance of hydrocarbon fill for reservoir quality prediction sandstones. AAPG Bull., 86, 9, 1561-1571.

Mitchum R. M., Vail P. R., Sangree J. B., 1977: Seismic stratigraphy and global changes of sea level, Part 6: Stratigraphic interpretation of seismic reflection patterns in depositional sequences. In: Payton C. E. (Ed.): Seismic stratigraphy - applications to hydrocarbon exploration. AAPG Mem., Tulsa, Okla., USA, 26, 117-133, doi: 10.1306/M26490C8.

Mitchum R. M., Hoffman M. W., Conners C. D., Knowlton A. M., Radovich B. J., 2000: Tectonic controls on regional sequence stratigraphy in the Niger Delta, offshore Nigeria (abstract). AAPG Annual Meeting Program, 9, A99.

Morley C. K., Guerin G., 1996: Comparison of gravity-driven deformation styles and behavior associated with mobile shale and salt. Tectonics, 15, 6, 1154-1170, doi: 10. 1029/96TC01416.

Neal J., Risch D., Vail P., 1993: Sequence stratigraphy-A global theory for local success. Oilfield Rev., 5, 1, 51-62.

Obi I. S., Ezeagwuna C. A., Popoola O. W., 2018: Trap styles and polyphaser structural deformation of deepwater sediments in greater triangular bulge (GTB) area, eastern Niger Delta - offshore West Africa. NAPE Bull., 27, 2, 29-36.

Ojo A. O., 1996: Pre-drill prospect evaluation in deep water Nigeria. NAPE Bull., 11, $11-22$.

Reijers T. J. A., Petters S. W., Nwajideet C. S., 1997: Chapter 7 - The Niger Delta basin. In: Selley R. C. (Ed.): African Basins, Vol. 3, Sedimentary Basins of the World, Amsterdam, Elsevier Science, 151-172, doi: 10.1016/S1874-5997(97)80010-X.

Rider M. H., Kennedy M., 2011: The Geological Interpretation of well logs. 3rd Edition, Rider-French Consulting Ltd., 440 p.

Short K. C., Stauble A. J., 1967: Outline of geology of Niger Delta. AAPG Bull., 51, 5, 761-779.

Smith W. H. F., Sandwell D. T., 1997: Global sea floor topography from satellite altimetry and ship depth soundings. Science, 277, 5334, 1956-1962, doi: 10.1126/science. 277.5334.1956.

Thomas D., 1995: Exploration gaps exist in Nigeria's prolific delta. Oil Gas J., 93, 44, $66-71$.

Whiteman A. J., 1982: Nigeria: Its Petroleum Geology, Resources and Potential. Graham \& Trotman, London, $394 \mathrm{p}$.

Wu S., Bally A. W., 2000: Slope tectonics-comparisons and contrasts of structural styles of salt and shale tectonics of the northern Gulf of Mexico with shale tectonics of offshore Nigeria in Gulf of Guinea. In: Mohriak W., Talwani M. (Eds.): Atlantic Rifts and Continental Margins. Geophys. Monogr. Ser., 155, AGU, Washington, D.C., 151-172, doi: 10.1029/GM115p0151. 